\title{
Kemungkinan Mekanisme Peran Zink Dalam Patogenesis Covid-19
}

\author{
Moch Ikhsan Juliansyah*, Lisa Adhia Garina \\ Prodi Pendidikan Kedokteran, Fakultas Kedokteran, Universitas Islam \\ Bandung, Indonesia. \\ *ikhsanjuliansyah25@gmail.com, lisa.adhia@gmail.com
}

\begin{abstract}
This study was conducted to gather sufficient information on the possible mechanism of the role of zinc in the pathogenesis of COVID-19. The method used in this study is a literature study that collects several previous studies to determine the possible mechanism of the role of zinc in the pathogenesis of COVID-19. The results of this study indicate that there are various possible mechanisms of the role of zinc in the pathogenesis of COVID-19 such as preventing virus entry by increasing epithelial integrity, increasing the ability of mucociliary clearance mechanisms, decreasing ACE-2 receptor expression, preventing viral replication by inhibiting RNA polymerase, eliminating viruses by destabilizing them. viral envelope, regulates the immune system such as activation of natural killer cells, cytotoxic T cells, amplifies $\mathrm{B}$ cell receptor signaling, antibody formation and regulates regulatory $\mathrm{T}$ cell activity and expression of nuclear factor kappa B to maintain a balanced immune response. Thus, it can be said that zinc has a possible role mechanism in the pathogenesis of COVID-19 by preventing the virus from entering, making virus replication, eliminating the virus, and maintaining a balance of immune responses when someone is exposed to COVID-19.
\end{abstract}

Keywords: COVID-19, SARS-CoV-2, Pathogenesis, Zinc.

\begin{abstract}
Abstrak. Studi ini dilakukan untuk mengumpulkan informasi yang cukup terhadap kemungkinan mekanisme peran zink dalam patogenesis COVID-19. Metode yang digunakan dalam studi ini adalah studi literatur yang mengumpulkan beberapa penelitian terdahulu untuk mengetahui kemungkinan mekanisme peran zink dalam patogenesis COVID-19. Hasil dari studi ini menunjukan adanya berbagai kemungkinan mekanisme peran zink dalam patogenesis COVID-19 seperti mencegah virus masuk dengan meningkatkan integritas epitel, meningkatkan kemampuan mekanisme mucociliar clearance, menurunkan ekspresi reseptor ACE-2, mencegah replikasi virus dengan menghambat RNA polimerasenya, mengeliminasi virus dengan mendestabilisasi envelop virus, meregulasi sistem imun seperti aktivasi sel natural killer, sel $\mathrm{T}$ sitotoksik, memperkuat penyinalan reseptor sel $\mathrm{B}$, pembentukan antibodi dan meregulasi aktivitas sel T regulator dan ekspresi nuclear factor kappa B untuk mempertahankan keseimbangan respon imun. Dengan demikian dapat disimpulkan bahwa zink memiliki kemungkinan mekanisme peran dalam patogenesis COVID-19 dengan cara mencegah virus masuk, mencegah replikasi virus, mengeliminasi virus dan menjaga keseimbangan respon imun pada saat seseorang terkena COVID-19.
\end{abstract}

Kata Kunci: COVID-19, SARS-CoV-2, Patogenesis, Zink. 


\section{A. Pendahuluan}

Sejak 11 Maret 2020 World Health Organizatio (WHO) mengumumkan bahwa dunia sedang menghadapi penyakit infeksi saluran pernapasan yang disebut dengan Coronavirus Disease 2019 (COVID-19). WHO melaporkan sudah terdapat lebih dari 300 juta kasus terkonfirmasi COVID-19 dimana lebih dari 5 juta diantaranya meninggal dunia. ${ }^{1,2}$

Dalam penanganan kasus COVID-19, dokter dapat menggunakan berbagai macam pilihan terapi yang dinilai berpotensi untuk meningkatkan angka kesembuhan pasien COVID19 seperti agen anti-inflamasi, obat antivirus, terapi seluler, imunoterapi serta terapi tambahan seperti pemberian senyawa alami. ${ }^{3}$

Salah satu senyawa alami yang direkomendasikan adalah zink. Zink adalah essensial trace element yang berperan dalam mempertahankan fungsi penglihatan, persepsi rasa, kognisi, reproduksi sel, pertumbuhan, proses pembekuan darah, penyembuhan luka, perkembangan janin, imunitas dan fungsi lainnya. Pada penelitian yang dikemukakan oleh Prasad (2008) yang menunjukan pengaruh defisiensi zink terhadap ketidakseimbangan respon imun tubuh manusia. Penelitian lain yang dilakukan oleh Velthuis (2010) menunjukan adanya kemampuan zink sebagai agen antivirus bagi coronavirus dengan cara menghambat aktivitas RNA polimerase virus. Sehingga pemberian suplementasi zink diduga dapat berdampak baik bagi pasien COVID19. $4,5,6,7$

Rekomendasi asupan zink harian pria sebanyak $11 \mathrm{mg} / \mathrm{hari}$ dan wanita $8 \mathrm{mg} / \mathrm{hari}$ dengan batas toleransi asupan zink orang dewasa adalah $40 \mathrm{mg} / \mathrm{hari}$. Inernational Zinc Nutrition Consultative Group (IZiNCG) menentukan konsentrasi serum zink $<70 \mu \mathrm{g} / \mathrm{dL}$ sebagai kondisi defisiensi. Zink bisa didapatkan dari makanan seperti daging, makanan laut, unggas, kacangkacangan dan suplemen zink. ${ }^{5,8}$

Beberapa penelitian yang dilakukan oleh Vogel-González (2021), Yasui (2020) dan Jothimani (2020) mendapatkan temuan bahwa defisiensi zink pada pasien COVID-19 yang dirawat di rumah sakit memiliki derajat keparahan yang lebih buruk, meningkatkan durasi rawat inap dan meningkatkan angka kematian. Penelitian terkait pemberian suplementasi zink terhadap pasien COVID-19 yang dilakukan oleh Frontera (2020) dan Carlucci (2020) menunjukan adanya peningkatan angka kesembuhan pada pasien COVID-19 yang mendapatkan terapi tambahan zink pada saat dirawat di rumah sakit. ${ }^{9-14}$

Kendati jika dilihat dari hasil penelitian yang telah dilakukan zink memegang peranan yang cukup penting dalam perkembangan kondisi pasien COVID-19, mekanisme bagaimana zink ini dapat mempengaruhi perkembangan kondisi pasien COVID-19 belum dapat dijelaskan secara jelas dan pasti.

Sehingga mengacu pada latar belakang masalah yang telah diuraikan di atas, diperoleh rumusan masalah sebagai berikut : "Bagaimana kemungkinan mekanisme peran zink dalam patogenesis COVID-19?". Selanjutnya, tujuan dalam penenlitian ini diuraikan dalam pokokpokok sebagai berikut: "Mengetahui kemungkinan mekanisme peran zink dalam patogenesis COVID-19".

\section{B. Metodologi Penelitian}

Peneliti Jenis penelitian ini adalah studi literatur. Zed dalam penelitian Kartiningsih (2015) mengatakan bahwa metode studi literatur adalah serangkaian kegiatan yang berkenaan dengan metode pengumpulan data pustaka, membaca dan mencatat, serta mengelolah bahan penelitian. Kartiningsih menambahkan bahwa Studi kepustakaan dilakukan oleh setiap peneliti dengan tujuan utama yaitu mencari dasar pijakan/fondasi untuk memperoleh dan membangun landasan teori, kerangka berpikir, dan menentukan dugaan sementara atau disebut juga mengorganisasikan, dan menggunakan variasi pustaka dalam bidangnya. Sedangkan populasi pada penelitian ini adalah jurnal internasional berbahasa Inggris dengan akses penuh yang membahas mengenai fungsi zink dalam sistem imun. 
118 | Moch Ikhsan Juliansyah, et al.

\section{Hasil Penelitian dan Pembahasan}

Coronavirus Disease 2019

Coronavirus disease 2019 (COVID-19) adalah penyakit yang disebabkan karena infeksi Severe Acute Respiratory Syndrome Coronavirus 2 (SARS-CoV-2).16 COVID-19 utamanya ditransmisikan melalui droplet pasien terinfeksi SARS-CoV-2.

\section{Patogenesis Covid-19}

Berdasarkan Severe Acute Respiratory Syndrome Coronavirus 2 (SARS-CoV-2) adalah bakteri dengan ribonucleic acid (RNA) positive sense berenvelop yang tergolong kedalam $\beta$ coronavirus. SARS-CoV-2 memiliki protein spike (S) yang berfungsi membantu virus masuk kedalam sel, envelope (E) dan membrane (M) yang berfungsi untuk menggabungkan komponen virus dan mengemas genom menjadi virion, serta nukleokapsi $(\mathrm{N})$ yang berfungsi untuk menghambat penyinalan IFN- $\beta$. Patogenesis COVID-19 dapat dibagi menjadi tiga fase yang terdiri dari: fase awal infeksi, fase paru-paru dan fase hiperinflamasi. ${ }^{3}$

Fase awal infeksi dimulai ketika protein S pada droplet SARS-CoV-2 berikatan dengan reseptor angiotensin converting enzyme 2 (ACE-2) pada epitel saluran pernafasan dan Transmembrane Serine Protease 2 (TMPRSS2) memfasilitasi pembelahan S protein menjadi S1 dan S2. Dimana subunit S2 menyebabkan virus mampu fusi dengan membrane sel inang. Setelah masuk ke dalam sel inang, virus akan melepaskan RNAnya dan mengalami replikasi. Virus memiliki sistem pertahanan dari protein $\mathrm{N}$ yang dapat menghambat penyinalan IFN- $\beta$ dan lama waktu inkubasi yang memungkinkan virus menghindari respon imun innate. ${ }^{3}$

Fase paru-paru ditandai dengan adanya peradangan, kerusakan jaringan dan kegagalan pernafasan. Proses eksositosis virus diyakini menyebabkan kerusakan pada sel alveolar tipe 2. Kerusakan sel ini akan memicu respon peradangan dan menyebabkan adanya peningkatan level stress oksidatif dan mediator proinflamasi sehingga kerusakan jaringan lebih besar dan menyebabkan peningkatan permeabilitas endotel dan epitel pari-paru sehingga terdapat akumulasi cairan dan menyebabkan difusi oksigen pada proses pernafasan terhambat. ${ }^{3}$

Terhambatnya proses pertukaran oksigen ini menyebabkan kondisi hipoksia. Akibat dari proses peradangan yang diperparah dengan kondisi hipoksia ini akan berujung pada pembentukan jaringan parut di epitel paru-paru dan dapat berujung pada Acute Respiratory Distress Syndrome (ARDS). ${ }^{3}$ 


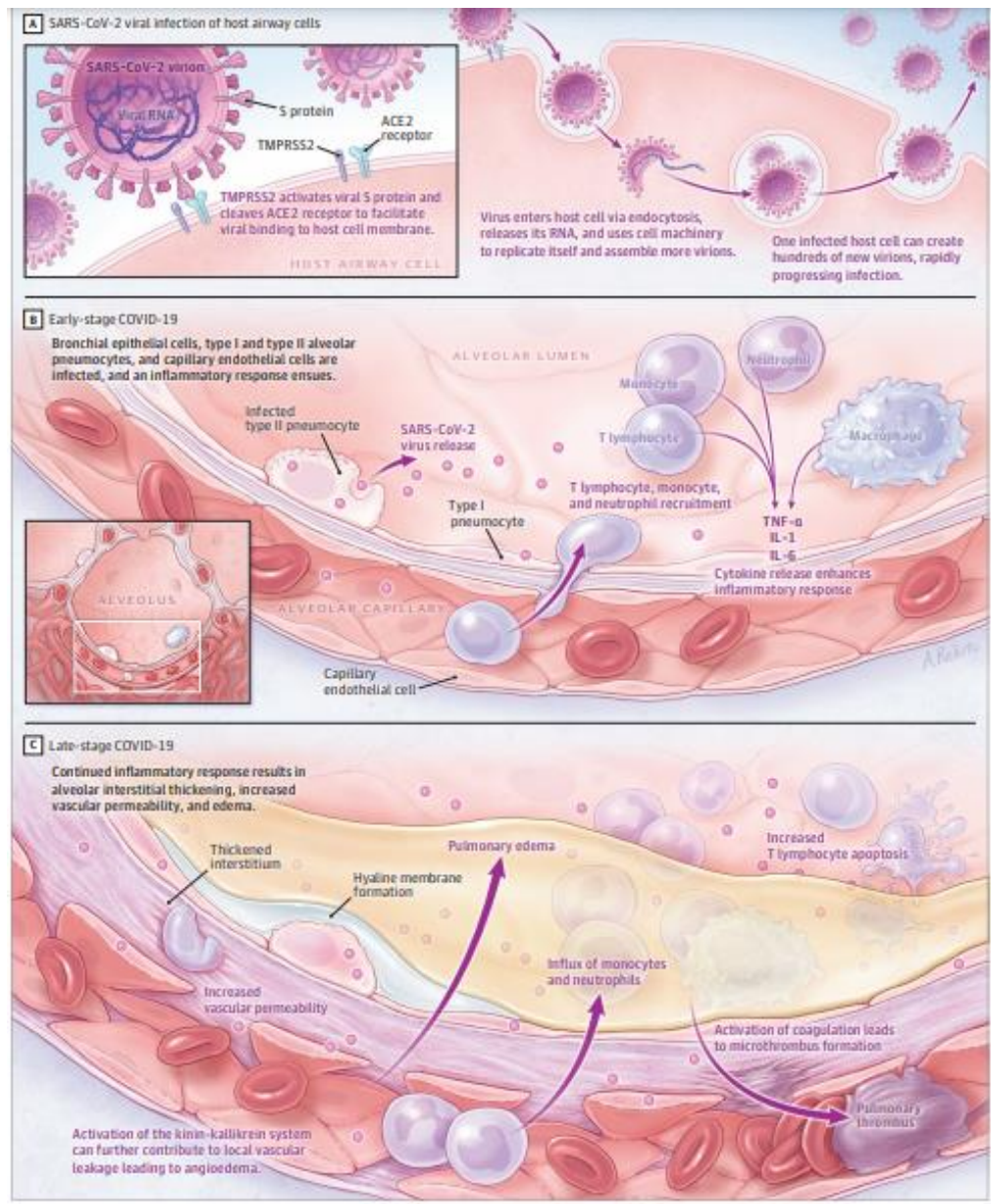

Gambar 1. Patogenesis COVID-19

\section{Dikutip dari: Wiersinga W. J.3}

Fase hiperinflamasi ditandai dengan adanya proses peradangan sistemik, kerusakan organ selain paru-paru dan keadaan hiperkoagulasi yang dapat mengakibatkan Multiorgan Failure (MOF). Tingginya kadar leukosit dengan lymphopenia dan level sitokin pro-inflamasi yang tinggi terutama interleukine (IL-2), IL-6, IL-7, IL-10, C-reactive protein (CRP), granulocyte-colony stimulating factor (G-CSF), interferon-gamma inducible protein (IP) 10 , monocyte chemoattractant protein (MCP) 1 , macrophage inflammatory protein (MIP) $1 \alpha$, and tumor necrosis factor (TNF) $\alpha$. Tingginya kadar sitokin ini disebut dengan badai sitokin yang menyebabkan kerusakan paru-paru lebih parah dengan komplikasi seperti multiple organ failure, acute respiratory distress syndrome, syok septik, hemorrhage/coagulopathy, acute heart/liver/kidney injury bahkan kematian.

\section{Zink}

Zink adalah essensial trace element yang berperan dalam proses penglihatan, persepsi rasa, kognisi, reproduksi, pertumbuhan dan imunitas. Rekomendasi asupan harian zink bagi pria adalah $11 \mathrm{mg} / \mathrm{hari}$ dan $8 \mathrm{mg} / \mathrm{hari}$ bagi wanita dengan batas toleransi asupan harian sampai 40 $\mathrm{mg} / \mathrm{hari}$ bagi orang dewasa. International Zinc Nutrition Consultative Group (IZiNCG) menyatakan kondisi defisiensi zink ditentukan dengan konsentrasi serum zink $<70 \mu \mathrm{g} / \mathrm{dL}$. Zink bisa didapatkan dari makanan seperti tiram, daging sapi, unggas, dan kacang-kacangan serta dari suplemen zink. 


\section{Kemungkinan Mekanisme Peran Zink pada Patogenesis COVID-19}

Zink diketahui mampu untuk memodulasi respon imun manusia. Ketika kadarnya adekuat zink mampu meningkatkan respon imun terhadap infeksi berbagai virus. Ketika dalam kondisi defisiensi zink seseorang terbukti memiliki kerentanan yang lebih tinggi terhadap virus. Dari fungsi zink dalam memodulasi sistem imun manusia terdapat berberapa kemungkinan mekanisme peran zink dalam patogenesis COVID-19 seperti mencegah virus masuk, mengeliminasi virus dan menyeimbangkan respon imun.

\section{Zink Mencegah Virus Masuk Ke dalam Tubuh Inang}

Zink diketahui memiliki efek untuk meningkatkan jumlah dan menambah panjang silia bronkial pada sampel tikus. Kadar zink yang adekuat juga terbukti memiliki kemampuan untuk meningkatkan frekuensi gerak silia. Dengan bertambahnya jumlah silia, memanjangnya ukuran silia dan meningkatnya frekuensi gerak silia ini akan meningkatkan kemampuan mucociliar clearance dari saluran pernafasan untuk mencegah virus masuk ke dalam tubuh. ${ }^{5,18}$

Ketika kadar zink adekuat ekspresi protein membran seperti claudin-1 dan ZO-1 akan meningkatkan fungsi barrier epitel respirasi. Dengan terpenuhinya kebutuhan zink tubuh akan memperkuat epitel sistem respirasi lebih tahan terhadap kerusakan akibat ventilasi mekanik sehingga mencegah terbentukany jalur masuk dari virus ke dalam sel inang. Sedangkan kondisi defisiensi zink dikaitkan erat dengan peningkatan resiko kebocoran epitel respirasi, hanya saja kondisi ini bersifat reversible dengan pemberian splementasi zink..$^{5,18}$

Kadar zink yang tinggi akan menghambat ekspresi reseptor ACE-2 akibat induksi sirtuin 1 (SIRT-1) sehingga mengurangi interaksi antara virus dengan sel tubuh inang.

\section{Zink Menginhibisi Replikasi dan Mengeliminasi Virus}

Zink mampu untuk menginhibisi replikasi virus dengan bebagai macam cara seperti menghambat pelepasan partikel virus, menghambat kerja dari RNA polimerase vurs dan menyebabkan ketidakstabilan envelop virus. Diketahui pemberian zink disertai zink ionofor efektif dalam menginhibisi RNA-dependent RNA polymerase (RdRp) pada virus SARS-CoV. ${ }^{5,7,18}$

Zink mengeliminasi virus dengan cara meningkatkan produksi IFN $\alpha$ oleh leukosit yang berdampak terhadap peningkatan sintesis protein antivirus seperti latent ribonuclease \& protein kinase RNA-activated sehingga RNA virus akan terdegradasi. Zink diketahui memiliki peran dalam mengaktivasi natural killer cell (sel NK), sel T sitotoksik, memperkuat penyinalan reseptor sel $\mathrm{B}$ dan pembentukan antibodi untuk mengeliminasi virus dan mencegah virus melekat pada reseptor pada tubuh inang.

\section{Zink Menyeimbangkan Respon Imun}

Salah satu tanda khas dari COVID-19 adalah adanya ketidakseimbangan respon imun yang ditandai dengan tingginya mediator proinflamasi dan rendahnya sitokin anti-inflamasi sehingga terjadilah kondisi badai sitokin akibat hiperinflamasi yang sering berakhir dengan adanya ARDS pada pasien COVID-19. Kondisi ini bisa diperburuk dengan kondisi defisiensi zink karena zink memiliki kemampuan untuk mengatur promosi dan supresi sistem imun. ${ }^{5,18,19,20}$

Zink memiliki kemampuan untuk mempengaruhi proses maturasi dari sel B untuk respon imun adaptif dan regulator dari Toll Like Receptor 3 (TLR-3) \& TLR-4 yang berperan dalam respon imun innate. Zink memiliki kemampuan untuk membentuk ikatan zink-sulfur yang mengakibatkan zink mampu bertindak sebagai zat antioksidan sehingga akan mengurangi jumlah reactive oxygen species (ROS) dan reactive nitrogen species (NOS). Zink juga terlibat dalam regulasi dari aktivasi sel $\mathrm{T}$ regulator untuk mencegah hiperaktivitas respon imun. Zink juga berperan dalam meregulasi keseimbangan sekresi sitokin proinflamasi dan anti-inflamasi. , $^{5,18,21,22}$

Kemungkinan mekanisme ini diperkuat degan kondisi defisiensi zink yang diketahui dapat menyebabkan peningkatan ekspresi dari nuclear factor kappa $B$ (NF-kB) yang menyebabpkan penurunan sintesis superoxide dismutate (SODs) yang menyebabkan peningkatan pelepasan mediator proinflamasi dan reactive oxygen species (ROS) yang akan menyebabkan kerusakan sel secara permanen. Selain dari peningkatan ekspresi NF-kB, defisiensi zink diketahui menyebabkan terjadinya penurunan cascade sinyal sel T. Kondisi ini 
akan menyebabkan ketidakmampuan sistem imun untuk mengiliminasi virus yang masuk ke dalam tubuh inang, hal ini ditemukan pada sampel mencit yang menunjukan gambaran neutrofilia dan limfopenia yang bersifat reversible dengan suplementasi zink.

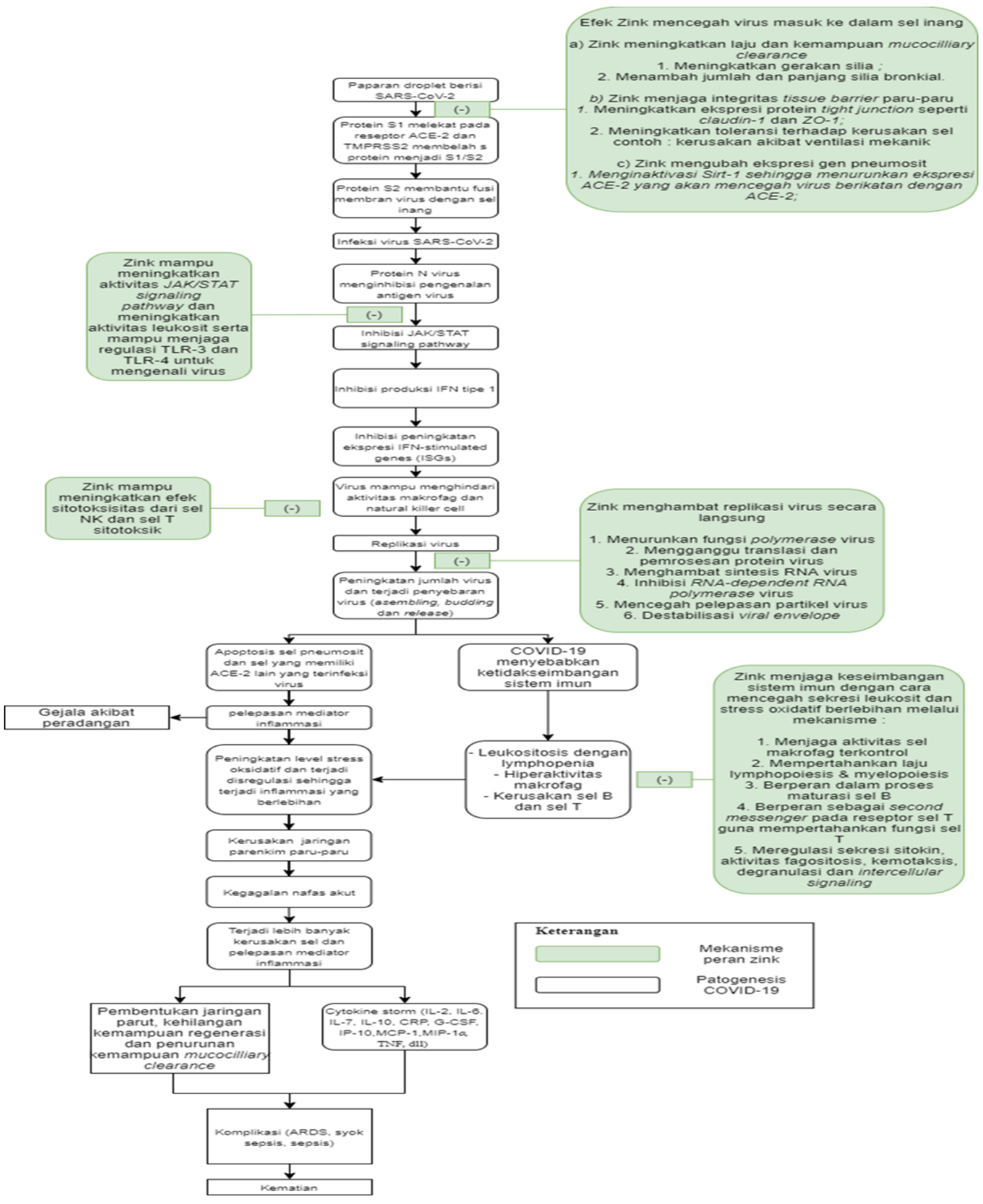

Gambar 2. Kemungkinan Mekanisme Peran Zink Dalam Patogenesis COVID-19

\section{Kesimpulan}

Zink memiliki berbagai kemungkinan mekanisme peran dalam patogenesis COVID-19 seperti mencegah virus masuk kedalam tubuh inang, mencegah replikasi virus, mengeliminasi virus dan menjaga keseimbangan respon imun tubuh pada saat sakit COVID-19. 


\section{Daftar Pustaka}

[1] World Health Organization [homepage pada internet]. Archived: WHO Timeline - COVID19 (Updated 2020 Apr 27; diunduh 31 Januari 2021]. Tersedia dari: https://www.who.int/news/item/27-04-2020-who-timeline---Covid-19.

[2] World Health Organization [homepage pada internet]. WHO Coronavirus Disease (COVID19) Dashboard [Updated 2021 Mar; diunduh 2 Maret 2021]. Tersedia dari: https://covid19.who.int/.

[3] Tsang HF, Chan LWC, Cho WCS, Yu ACS, Yim AKY, Chan AKC, dkk. An update on COVID-19 pandemic: the epidemiology, pathogenesis, prevention and treatment strategies. Expert Rev Anti Infect Ther. 2020;1-12.

[4] Samad N, Sodunke TE, Abubakar AR, Jahan I, Sharma P, Islam A, dkk. The implications of zinc therapy in combating the COVID-19 Global Pandemic. J Inflamm Res. 2021; 14:527-50 .

[5] Whitney E, Rolfes SR. Understanding nutrition. Edisi ke-14. Stamford. Cengage Learning;2016.

[6] Prasad AS. Zinc in human health: Effect of zinc on immune cells. Mol Med. 2008;14(56):353-7.

[7] Te Velthuis AJW, van den Worml SHE, Sims AC, Baric RS, Snijder EJ, van Hemert MJ. Zn2+ inhibits coronavirus and arterivirus RNA polymerase activity in vitro and zinc ionophores block the replication of these viruses in cell culture. PLoS Pathog. 2010;6(11):110.

[8] Hotz C, Brown KH. Assessment of risk of zinc deficiency in populations and options for its control. Toronto. International Nutrition Foundation for The United Nations University; 2004.

[9] Vogel-González M, Talló-Parra M, Herrera-Fernández V, Pérez-Vilaró G, Chillón M, Nogués X, dkk. Low Zinc Levels at Admission Associates with Poor Clinical Outcomes in SARS-CoV-2 Infection. Nutrients. 2021;13(2):1-13

[10] Yasui Y, Yasui H, Suzuki K, Saitou T, Yamamoto Y, Ishizaka T, dkk. Analysis of the predictive factors for a critical illness of COVID-19 during treatment - relationship between serum zinc level and critical illness of COVID-19. Int J Infect Dis. 2020;100:230-6

[11] Jothimani D, Kailasam E, Danielraj S, Nallathambi B, Ramachandran H, Sekar P, dkk. COVID-19: Poor outcomes in patients with zinc deficiency. Int J Infect Dis. 2020;100:3439

[12] Frontera JA, Rahimian JO, Yaghi S, Liu M, Lewis A, Havenon A de, dkk. Treatment with Zinc is Associated with Reduced In-Hospital Mortality Among COVID-19 Patients: A Multi-Center Cohort Study.

[13] Carlucci PM, Ahuja T, Petrilli C, Rajagopalan H, Jones S, Rahimian J. Zinc sulfate in combination with a zinc ionophore may improve outcomes in hospitalized COVID-19 patients. J Med Microbiol. 2020;69(10):1228-3422.

[14] Carlucci PM, Ahuja T, Petrilli C, Rajagopalan H, Jones S, Rahimian J. Hydroxychloroquine and azithromycin plus zinc vs hydroxychloroquine and azithromycin alone: outcomes in hospitalized COVID-19 patients.

[15] Kartiningsih, Eka Diah. Panduan Penyusunan Studi Literatur. Lembaga Penelitian dan Pengabdian Masyarakat Politeknik Kesehatan Majapahit Mojokerto. 2015.

[16] Yuen KS, Ye ZW, Fung SY, Chan CP, Jin DY. SARS-CoV-2 and COVID-19: The most important research questions. Cell Biosci. 2020;10(1):1-5.

[17] World Health Organization [homepage pada internet]. Coronavirus disease (COVID-19) [Updated 2021; diunduh 31 Januari 2021]. Tersedia dari: https://www.who.int/healthtopics/coronavirus\#tab=tab_3.18. Wessels I, Rolles B, Rink L. The Potential Impact of Zinc Supplementation on COVID-19 Pathogenesis. Front Immunol. 2020;11(July):1-11. 
[18] Hirano T, Murakami M, Fukada T, Nishida K, Yamasaki S, Suzuki T. Roles of Zinc and Zinc Signaling in Immunity: Zinc as an Intracellular Signaling Molecule. Adv Immunol. 2008;97(08):149-76.

[19] Kido T, Ishiwata K, Suka M, Yanagisawa H. Inflammatory response under zinc deficiency is exacerbated by dysfunction of the T helper type 2 lymphocyte-M2 macrophage pathway. Immunology. 2019;156(4):356-72.

[20] Besecker BY, Exline MC, Hollyfield J, Phillips G, DiSilvestro RA, Wewers MD, et al. A comparison of zinc metabolism, inflammation, and disease severity in critically ill infected and noninfected adults early after intensive care unit admission. Am J Clin Nutr. 2011;93(6):1356-64.

[21] Wong CP, Dashner-titus EJ, Alvarez SC, Chase TT, Laurie G, Ho E, et al. HHS Public Access. 2020;191(2):370-81. 